Jurnal Pembangunan Pendidikan: Fondasi dan Aplikasi

Volume 4, No 2, Desember 2016 (194-202)

Online: http://journal.uny.ac.id/index.php/jppfa

\title{
KEPEMIMPINAN (UNTUK) PEMBELAJARAN: JEMBATAN UNTUK MEMPERKUAT PEMBENTUKAN KARAKTER
}

\author{
Udik Budi Wibowo \\ Fakultas Ilmu Pendidikan Universitas Negeri Yogyakarta \\ udik_bw@uny.ac.id
}

\begin{abstract}
Abstrak
Pendidikan dipandang belum dapat melahirkan dalam jumlah banyak manusia pintar, bermoral, dan profesional, yang mampu mengedepankan nilai-nilai kemanusiaan dan ketaqwaan dalam perilaku keseharian. Sehubungan dengan itu kepemimpinan untuk pembelajaran dapat dijadikan strategi dan solusi guna menjawab keprihatinan bangsa tersebut. Kepemimpinan untuk pembelajaran berkaitan dengan pengelolaan penjaminan kualitas pembelajaran, yang dapat menciptakan lingkungan pembelajaran yang kondusif untuk mengembangkan potensi peserta didik seutuhnya sehingga dapat mencapai prestasi akademik dan non-akademik yang maksimal, serta bermanfaat bagi kehidupan sendiri dan lingkungannya. Kepemimpinan pembelajaran mengutamakan praktek-praktek pendidikan yang ideal dengan landasan kebenaran, keadilan, kemanusiaan, dan estetika (keindahan); sehingga dapat melahirkan insan-insan yang berkarakter mulia dan profesional.
\end{abstract}

Kata kunci: kepemimpinan untuk pembelajaran, kualitas pembelajaran, insan berkarakter, dan pengembangan sekolah

\section{LEADERSHIP (FOR) LEARNING: BRIDGE TO STRENGTHEN THE CHARACTER BUILDING}

Udik Budi Wibowo

Fakultas Ilmu Pendidikan Universitas Negeri Yogyakarta udik_bw@uny.ac.id

\begin{abstract}
Education couldn't have been produced a large number of peoples who smart, have high moral standards, and professional, yet; who capable to give priority to human values and faithful in daily live. In keeping with the nation concern, leadership for learning could be use as a strategy or an alternative solution. Leadership for learning concerned with learning quality assurance management, which can create condusive learning environment to develop the wholeness student potential, so he/she could reach maximum academic and non-academic achievement, which is worthwhile for him/her-self live, and the environment. Leaderhip for learning consider as most important the ideal of educational practices, based on truth, justice, humanity, and aesthetics; so it could provide a large number of noble and professional peoples.
\end{abstract}

Keywords: leadership for learning, learning quality, noble people, and school improvement 



\section{PENDAHULUAN}

Kekacauan, kekisruhan, kekerasan, dan ketidak-beresan yang semakin kentara meningkat dalam berbagai ranah kehidupan masyarakat pada saat ini, menimbulkan pertanyaan mendasar apa yang salah dalam pendidikan? Pendidikan pantas digugat, karena dari rahim pendidikan telah melahirkan sosoksosok tamak, hedonis-materialistis, atau individu-individu berperangai serigala berbulu domba, yang merusak sendi-sendi kebaikan kehidupan. Padahal kita tidak pernah mempertanyakan apa kerja ahli pertanian, dengan serbuan impor bahan pokok pangan dan buahbuahan yang semakin memiskinkan dan bahkan mematikan para petani negeri ini. Kita juga tidak pernah mempermasalahkan kinerja pakar dan pejabat perdagangan dengan kehadiran retail sebagai tempat belanja yang nyaman sampai ke pelosok-pelosok negeri yang membuat muram dan suram pemilik kios dan pasar tradisional. Semua kesalahan patut ditimpakan hanya kepada pendidikan, karena pendidikan dipandang belum dapat melahirkan dalam jumlah banyak manusia pintar, bermoral atau berkarakter, insan-insan bermental wirausaha, dan mampu mengedepankan nilai-nilai kemanusiaan dan ketaqwaan dalam perilaku keseharian.

Dakwaan kesalahan pendidikan di atas tidak sepenuhnya salah, karena seperti disinyalir oleh para pakar bahwa penyelenggaraan pendidikan selama ini lebih mementingkan pada aspek kognitif dan konatif (motorik), dan mengesampingkan aspek afektif. Proses pembelajaran di sekolah-sekolah saat ini, seperti dikemukakan oleh Wagner (2008, p. xiii) “... there's too much testing in schools now -and too many classes that merely 'teach to the tests' - where the focus on more on practice tests and test-taking strategies than on learning rich and challenging content". Pendidikan di sekolahsekolah sekarang ini lebih banyak mengajarkan cara-cara mengerjakan soal daripada mempelajari bahan ajar yang kaya dan menantang. Kenyataan umum, para siswa di sekolahsekolah dan diperkuat lagi di lembaga bimbingan belajar, diajarkan strategi mengerjakan soal untuk mendapatkan peringkat nilai tinggi, untuk kebanggaan diri, meraih suatu kejuaraan, dan masuk jenjang pendidikan selanjutnya; tanpa tahu makna dan fungsinya untuk meningkatkan kesejahteraan hidup bersama.

Kondisi pendidikan semacam itu sebenarnya sudah terjadi sejak jaman penjajahan politik dan pendidikan ala barat sebagaimanan dikritisi oleh Bapak Pendidikan Dewantara (1962, pp. 465-466), yang pada intinya menyatakan bahwa sistem pendidikan dari Barat hampir semata-mata mengutamakan pendidikan intelektual atau pikiran, yang selanjutnya menimbulkan intelektualisme. Dalam intelektualisme, yang berkuasa dalam jiwa manusia adalah alam nalar, sedangkan budi manusia seutuhnya terdesak (diktatur intelek). Lebih lanjut beliau menyatakan bahwa diktatur intelek dengam sendirinya menimbulkan dua macam tabiat manusia yang berbahaya untuk keselamatan dan kebahagiaan masyarakat, yaitu tabiat egoisme, dan materialisme atau mementingkan diri sendiri di atas kepentingan hidup bersama dan meninggalkan hidup kebatinan (agama, dan kesucian). Sinyalemen Bapak Pendidikan pada tahun 1934, tampak berlaku pula pada kondisi sekarang ini. Dewantara (1962, p. 466) menulis sebagai berikut.

\section{Kemunduran hidup-batinnya rakyat kita pada djaman ini, kemunduran tabiat-ta- biat berani, setia, budi-derma, berkorban $d s b$., hilangnya rasa-manusia merdeka, kekurangannya tjinta pada sesama ma- nusia, pendek kata kemunduran budi- pekerti atau "karakter" dari turunan kita djaman sekarang itulah akibat dari hawa intelektualisme.}

Kondisi penyelenggaraan pendidikan di tanah air saat ini tampak berulang seperti kondisi yang disampaikan Bapak Pendidikan pada delapan puluh tahun yang lalu. Dengan kondisi pendidikan yang memprihatinkan tersebut, maka tulisan ini mencoba memberikan alternatif pendidikan atau pembentukan karekter melalui kepemimpinan (untuk) pembelajaran berbasis nurani. Sebagaimana diketahui bahwa kepemimpinan memiliki peran strategis untuk mengarahkan dan mempengaruhi perilaku orang lain. Oleh karena itu dengan berlandaskan pada nurani, para pemimpin dapat memberikan pengaruh yang penuh kasih dan empati, yang dapat membangkitkan dan mengembangkan nilai-nilai insani dari dalam diri setiap individu untuk mencapai kesejahteraan hidup bersama. 


\section{PEMBAHASAN}

\section{Konsep Kepemimpinan (Untuk) Pembelajaran}

Kepemimpinan pembelajaran dalam tulisan ini dapat disama-artikan dengan kepemimpinan pendidikan, dan dalam terminologi Bahasa Inggris dapat dipersamakan dengan istilah-istilah "educative leadership", "educational leadership", "instructional leadership", atau "leadership for learning". Istilah yang disebut terakhir dapat dimaknai kepemimpinan untuk pembelajaran, sehingga judul dan sub-judul dalam tulisan ini disisipkan kata "untuk" diantara kata kepemimpinan dan pembelajaran. Dua kata utama yang saling memerlukan, seperti dikemukakan John F. Kennedy (MacBeath, 2012, p. 3) bahwa "Leadership and learning are indispensable to one another".

Hallinger (2010, p. 127) mengajukan pemikiran bahwa istilah "instructional leadership" aslinya berfokus pada peran kepala sekolah; sedangkan "leadership for learning" menyarankan konseptualisasi yang lebih luas yang memasukan beragam sumber kepemimpinan dan fokus tindakan yang lebih luas, dalam kaitannya dengan pertumbuhan, proses dan hasil pembelajaran peserta didik, serta pengembangan sekolah. Adapun Duignan \& Macpherson (1992, p. 3) berpendapat bahwa kepemimpinan yang mendidik (educative leadership) berkaitan dengan cara-cara memahami organisasi dan cara-cara memimpin yang diekspresikan dalam norma-norma budaya kelompok, organisasi, atau sistem pendidikan. Duignan \& Macpherson (1992, p. 4) lebih lanjut menulis sebagai berikut.

Educative leadership is, therefore, concerned about right and wrong, justice and injustice, truth, aesthetics and the negotiation of practical ideals in education. It is concerned with an active analysis of the way things are, the way they are seen to $b e$, and with the creation of preferred ways of doing things.

Ungkapan tersebut dapat diartikan bahwa kepemimpinan yang mendidik pada dasarnya berkenaan dengan benar dan salah, adil dan tidak adil, kebenaran, estetika, dan negosiasi tentang praktek-praktek pendidikan yang ideal. Kepemimpinan ini berkaitan dengan suatu analisis aktif tentang arah ber- bagai hal, arah yang harus dituju, dan penciptaan cara-cara yang baik untuk mengerjakan sesuatu, untuk mencapai tujuan. Dalam kerja visioner, pemimpin yang mendidik selalu fokus pada segala sesuatu yang benar, melakukan pendampingan dan menjaga agar gagasan-gagasan yang benar tersebut dapat diterima dan dijalankan oleh berbagai pihak yang bersangkutan.

Selanjutnya Bush (2011, p.17) mengemukakan bahwa peningkatan penekanan pada pengelolaan belajar mengajar sebagai aktivitas inti dari institusi pendidikan telah mengarah kepada "instructional leadership" (kepemimpinan pembelajaran) atau "learningcentered leadership" (kepemimpinan berpusat pembelajaran). Lebih lanjut Bush (2011, p. 17) menyitir pendapat Rhodes \& Brundrett, bahwa konsep kepemimpinan berpusat pembelajaran memiliki potensi yang lebih besar untuk mempengaruhi outcomes sekolah dan siswa. Kepemimpinan pembelajaran berkenaan dengan penjaminan kualitas mengajar, sementara itu kepemimpinan (untuk) pembelajaran menggabungkan spektrum yang lebih luas dari tindakan kepemimpinan untuk mendukung pembelajaran dan hasil-hasilnya.

Pengertian yang luas semacam itu juga disampaikan oleh Brown \& Chai (2012, p. 753) sebagai berikut.

The term instructional, or learning-focussed leadership, embraces a number of leadership practices, including setting and communicating clear instructional goals and expectations; strategic resourcing of priority goals; overseeing and evaluating teaching and teachers; promoting and participating in teacher learning and development and creating an orderly environment that is safe for and supportive of both staff and students.

Pendapat tersebut dapat diartikan bahwa pengertian pembelajaran dalam kepemimpinan berfokus pada pambelajaran, mencakup praktek-praktek kepemimpinan, meliputi merancang dan mengkomunikasikan berbagai tujuan pembelajaran dan hasil yang diharapkan secara jelas, strategi alokasi sumber daya untuk tujuan-tujuan yang menjadi prioritas, mengawasi dan mengevaluasi pembelajaran dan gurunya; meningkatkan dan berpartisipasi dalam pembelajaran guru, serta menciptakan lingkungan yang tertib yang 
aman dan mendukung pendidik dan peserta didik.

Sementara itu Ezzaki (Townsend \& MacBeath. eds., 2011, pp. 128-129) mengartikan "Leadership for learning" sebagai upaya menggugah atau menginspirasi perubahan yang bersifat positip, dan mengambil tanggung jawab untuk memobilisasi para pendidik ke arah tujuan bersama, suatu visi sistem secara meluas terkait dengan kebutuhan berbagai peningkatan yang dapat berupa pembaharuan berskala kecil dan besar. Tanggung jawab tersebut mencakup tidak hanya rancangan perubahan, tetapi juga prosedur implementasinya, meliputi komunikasi, pelatihan, dan aktivitas tindaklanjutnya.

Kepemimpinan (untuk) pembelajaran juga dipahami sebagai seperangkat program dan tindakan yang mengarahkan ke cara meningkatkan prestasi peserta didik, dan menempatkan kualitas pembelajaran sebagai pusat agenda pendidikan. Kualitas pembelajaran yang dimaksudkan tidak hanya sekedar terkait dimensi internal, yaitu kinerja sistem sekolah pada indikator-indikator kritis seperti prestasi akademik peserta didik dalam ujian atau mengerjakan test, tingkat kebetahan sekolah, tingkat kenaikan kelas, penyelesaian, dan kesetaraan gender; tetapi juga mencakup dimensi ekternal, yaitu kepedulian terhadap kegunaan praktis dari pembelajaran akademik, yang terkait dengan dunia nyata, yang seringkali disebut relevansi pendidikan. Dengan demikian kepemimpinan pembelajaran (Ezzaki dalam Townsend \& MacBeath. eds., 2011, p. 129) mencakup “...quality learning, innovation, initiative, modelling of behaviour, or the development of community learning" (kualitas pembelajaran, inovasi, inisiatif, modeling perilaku, atau pengembangan komunitas pembelajaran). Hallinger (2009, p. 16) juga mengemukakan hal yang lebih kurang sama, bahwa kepemimpinan (untuk) pembelajaran mengintegrasikan fitur-fitur kependidikan mendasarkan pada berbagai konsepsi kepemimpinan pembelajaran dengan fiturfitur yang terseleksi dari model transformasional seperti modeling, fokus individu, dan kapasitas pengembangan.

Uraian di atas menunjukkan bahwa kepemimpinan untuk pembelajaran berkaitan dengan pengelolaan penjaminan kualitas pembelajaran, mulai dari merancang dan mengkomunikasikan secara jelas tentang tujuan dan hasil pembelajaran yang diharapkan, menentukan strategi pengalokasian sumberdaya sesuai dengan prioritas, dan melakukan pengawasan dan evaluasi pembelajaran; yang dapat menciptakan lingkungan pembelajaran yang kondusif untuk mengembangkan potensi peserta didik seutuhnya sehingga dapat mencapai prestasi akademik dan non-akademik yang maksimal yang bermanfaat bagi kehidupan diri dan lingkungan sekitarnya. Kepemimpinan pembelajaran mengutamakan praktekpraktek pendidikan yang ideal dengan landasan kebenaran, keadilan, kemanusiaan, dan estetika (keindahan); sehingga dapat melahirkan insan-insan yang berkarakter mulia dan profesional.

\section{Kepemimpinan Pembelajaran Yang Efektif}

Ezakki (Townsend \& MacBeath. eds., 2011, pp. 140-142) mengemukakan beberapa karakteristik kepemimpinan pembelajaran, yaitu: pertama, bahwasanya kepemimpinan pembelajaran bukan monopoli individu atau kelompok individu tertentu, tetapi juga dapat terjadi pada tingkat institusi; dan tidak terbatas pada sektor pendidikan. Kelompok profesional dan lembaga-lembaga khusus dapat mengambil inisiatif dan berkontribusi terhadap pembelajaran siswa, dengan beragam cara. Sehingga kepemimpinan pembelajaran dapat dikatakan bersifat multidimensional dan multilateral. Kedua, kepemimpinan pembelajaran memiliki target berupa kualitas pembelajaran, baik mencakup hasil maupun proses, tak peduli yang menerima keuntungan adalah peserta didik atau komunitas profesional pendidik. Pembelajaran harus dijalankan pada tingkat setinggi mungkin, tindakan-tindakan yang diambil harus mencerminkan pencarian keunggulan. Ketiga, kepemimpinan pembelajaran terdiri dari aktivitas-aktivitas inti tertentu, dari beragam pihak dan peran mereka. Tindakan-tindakan tersebut mencakup: mengambil inisiatif dan memperhitungkan resiko, melakukan pembaharuan, pemodelan, penyelesaian masalah, perencanaan, pelaksanaan, evaluasi, komunikasi, mobilisasi dan kolaborasi. Oleh karena itu perlu didukung dengan nilai-nilai tertentu seperti rasa perubahan positif, pengarahan tujuan, dan ketekunan. Dan keempat, bahwa kepemimpinan pembelajaran dipengaruhi oleh beberapa faktor yang dapat meningkatkan atau menurunkan kepemimpinan. Faktor terpenting terkait dengan kon- 
disi kerja, ketersediaan sumber daya, kebijakan dan manajemen, pelatihan, dan status profesional, dan kultur profesional, khususnya sejauh mana inisiatif dan kreativitas memperoleh dukungan dari berbagai pihak.

Selanjutnya berdasarkan pendapat Niece (Whitaker, 1997, p. 155) dapat dikemukakan tiga karakteristik pemimpin pembelajaran yang efektif, yakni: pertama, beorientasi pada orang dan berinteraksi secara intensif dengan warga sekolah, dan selalu hadir serta mudah dihubungi; kedua, berfungsi dalam jaring ke-sejawatan, baik bersifat formal maupun informal, pada tingkat lokal, regional, nasional, maupun internasional; dan ketiga, dapat bertindak selaku mentor atau penasehat. Pemikiran Niece tersebut tampak merujuk terutama pada aspek kemanusiaan atau sosial, perlu kecerdasan sosial. Hal ini sejalan dengan pendapat Crawford (2009, p. 124) yang menyatakan bahwa kepemimpinan pendidikan secara fundamental bicara tentang manusia, dan manusia perlu bekerja dalam konteks emosional, secara intra-personal (ke dalam diri) dan secara interpersonal (dalam hubungan dengan individu lain). Berdasarkan pendapat tersebut, bahwa kepemimpinan pembelajaran terkait dengan konteks hubungan intra dan inter-personal, maka semakin memperkuat bahwa kepemimpinan pembelajaran dapat dijadikan sarana untuk memantapkan pembentukan karakter humanis.

Hallinger (2010: 127) menggambarkan kerangka konseptual kontribusi kepemimpinan pembelajaran terhadap outcome pembelajaran, dan pengembangan lembaga sekolah sebagai berikut.

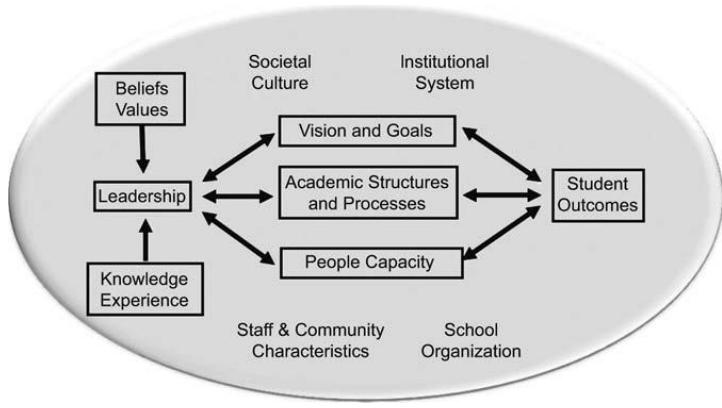

(Sumber: Hallinger, 2010, p. 127)

Gambar 1. Kontribusi Kepemimpinan

Pembelajaran terhadap Hasil Belajar Peserta Didik

Hallinger menyebutkan bahwa konsepsi kepemimpinan (untuk) pembelajaran di atas mengandung beberapa asumsi penting, yang secara ringkas dapat dijelaskan seperti berikut. Pertama, menekankan bahwa kepemimpinan berperan dalam konteks keorganisasian dan lingkungannya. Dalam organisasi sekolah, kepemimpinan berlangsung dalam "sistem terbuka" yang terdiri atas tidak hanya sistem kelambagaan dan budaya sosial, tetapi juga mencakup masyarakat dalam arti luas. Keefektifan kepemimpinan pembelajaran dapat semakin meningkat ditempa oleh pengalaman menghadapi berbagai hambatan dan memanfaatkan berbagai peluang yang ada di dalam organisasi sekolah dan lingkungannya. Kedua, pelaksanaan kepemimpinan dilandasi oleh karakteristik pemimpin itu sendiri, seperti nilai-nilai, keyakinan, pengetahuan, dan pengalaman; sebagai sumber perbedaan praktek kepemimpinan. Ketiga, kepemimpinan pembelajaran berdampak tidak secara langsung terhadap pembelajaran peserta didik; yakni melalui berbagai proses sekolah dan kondisi, seperti: visi dan tujuan yang ditetapkan, proses pembelajaran, dan kapasitas pendidik dan tenaga kependidikan.

Pada bagian lain Hallinger (2010, pp. 128-136) mengemukakan elemen kepemimpinan untuk pembelajaran yang dapat menentukan pengembangan sekolah dan hasil pembelajaran peserta didik, yaitu: nilai-nilai kepemimpinan (values leadership), fokus kepemimpinan (leadership focus), konteks kepemimpinan (context for leadership), dan kepemimpinan berbagi (sharing leadership).

Nilai-nilai merupakan tujuan akhir atau cita-cita dan juga cara-cara untuk mencapai tujuan atau cita-cita tersebut, melalui pekerjaan yang dipilih. Nilai-nilai ini pada umumnya berasal dari nilai kultural atau personal. Nilai-nilai yang menjadi pegangan dalam pelaksanaan kepemimpinan dapat sebagai nilai-nilai antara atau "terminal values" (seperti: pertumbuhan belajar, prestasi akademik, pengembangan sosial, pemerataan pendidikan, atau kebajikan). Adapun cara atau strategi untuk mencapai tujuan termasuk dalam nilai-nilai instrumental "instrumental values" yang tampak dalam pelaksanaan kerja (seperti: disiplin diri, integritas, keterbukaan, perhatian, saling hormat, dan saling membantu). Nilai-nilai memperkaya pemikiran dan tindakan pemimpin dan menunjukkan perangkat yang potensial berguna untuk bekerja dalam, dan memperkuat budaya belajar sekolah. 
Selanjutnya, focus kepemimpinan merujuk kepada perangkat yang memberikan pengaruh tidak langsung kepada pencapaian belajar. Dalam hal ini ada tiga jalur pengaruh tidak langsung tersebut meliputi: (1) visi dan tujuan; (2) struktur dan proses akademik; dan (3) unsur manusia. Kepemimpinan berkewajiban mendorong ketiga komponen untuk mencapai kinerja yang maksimal; dan untuk itu perlu memperhatikan konteks kelembagaan sekolah dan lingkungannya. Konteks sekolah merupakan faktor penting untuk memahami kepemimpinan dan hasil pembelajaran peserta didik. Teori-teori kepemim-pinan, seperti pendekatan situasional dan kontingensi, menyarankan keefektifan kepemim-pinan bergantung kepada fitur yang dapat ditemukenali pada koneks dan situasi tempat kerja (seperti: struktur organisasi, ketersedia-an sumber daya, kewenangan, dan hubungan kerja). Perbedaan pelaksanaan kepemimpinan direkomendasikan untuk menghadapi dan menanggapi kondisi dan situasi yang berbeda atau berubah. Dalam kaitan ini perlu mempertimbangkan menerapkan kepemimpinan berbagi (sharing atau distributed leadership), yakni perilaku, tindakan, atau strategi kepemimpinan untuk melibatkan para pemangku kepentingan dalam pengambilan keputusan organisasi. Dengan peran serta dalam pengambilan keputusan tersebut maka dapat diharapkan dukungan yang kuat dari para pemangku kepentingan untuk mencapai keberhasilan pengembangan organisasi sekolah dan prestasi belajar peserta didik.

\section{Jembatan Untuk Memperkuat Karakter}

DeVita (2007, p. 4) dan Colvin (2007, p. 15) mengemukakan lebih kurang bahwa sesungguhnya kepemimpinan pendidikan merupakan "jembatan untuk reformasi sekolah", atau dapat menghubungan berbagai strategi pembaharuan. Kepemimpinan pendidikan dapat memperkenalkan beragam upaya reformasi dengan cara-cara yang tidak dapat dilakukan oleh pihak manapun, dapat menyediakan jembatan yang sangat penting antara inisiatif pembaharuan pendidikan yang sangat banyak, dan menjadikan pembaharuanpembaharuan tersebut untuk mengembangkan setiap peserta didik seutuhnya.

Sementara itu Vogel $(2012$, p. 2) mengemukakan bahwa "Teachers and school administrators impact how young people make sense of themselves and their world, respond to others, and how to carry out their roles as citizens, employees, family members, and friends" yang dapat diartikan bahwa para guru dan administrator sekolah berpengaruh terhadap bagaimana generasi muda menilai atau menghargai mereka sendiri dan dunia sekitarnya, dan bagaimana melaksanakan peran sebagai warga negara, pekerja, anggota keluarga, dan teman. Pada bagian lain Vogel (2012, p. 11) mengemukakan bahwa pemimpin pendidikan perlu menyadari kebutuhan peserta didik, yang memerlukan motivasi, perasaan dihormati dan dihargai, dan memiliki atmosfir belajar dimana komunikasi di antara semua yang terlibat dalam proses pembelajaran berlangsung secara terbuka, terus terang, intensif, dan jujur. Selain itu, pemimpin pendidikan perlu bekerja keras menyeimbangkan tujuan sekolah antara prestasi akademik dengan pertumbuhan peserta didik secara menyeluruh, baik secara sosial dan emosional, maupun secara intelektual.

MacBeath (2012, p. 5) dengan cerdas mengkonsepsualisasikan kepemimpinan untuk pembelajaran secara komprehensif dan jelas dalam gambar kue pengantin seperti berikut ini.

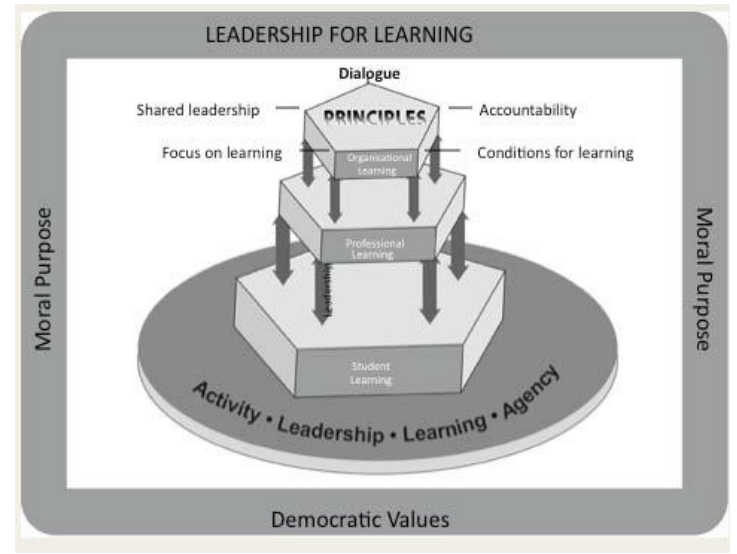

Sumber: MacBeath (2012: 5)

Gambar 2. Kepemimpinan untuk Pembelajaran

Gambar bingkai dari kue tersebut dimaksudkan untuk mengingatkan bahwa semua pemimpin dalam institusi pendidikan harus berpikir, bersikap, dan bertindak berdasarkan tujuan moral, dan nilai-nilai demokrasi. Moralitas dalam pendidikan bersifat normatif mengarah ke kebaikan, atau keutamaan hidup; yang dalam kehidupan bersama dinyatakan 
dalam nilai-nilai demokrasi. Gambar tersebut juga menunjukkan bahwa kepemimpinan untuk pembelajaran terdiri atas tiga tingkatan yang saling terkait dan saling mempengaruhi, yaitu: pembelajaran peserta didik, pembelajaran profesional, dan pembelajaran organisasional. Saling keterkaitan dapat dicontohkan bahwa peserta didik dapat belajar dengan baik jika guru memiliki kemampuan profesional; dan guru dapat menjalankan tugas dengan baik apabila sekolah dan/atau dinas dapat memfasilitasi peningkatan kinerja profesional guru secara berkelanjutan.

Ketiga tingkatan pembelajaran tersebut berdiri dalam landasan pokok yaitu kepemimpinan (leadership), dan pembelajaran (learning); yang diapit oleh keagenan (agency), dan kegiatan (activity). Agensi merujuk kepada tindakan proaktif dan penuh inisiatif dari pimpinan, yang menunjukkan keterwakilan, untuk berbagi kemampuan dan kebutuhan bersama. Adapun maksud kegiatan adalah sesuatu yang dikerjakan, yang berpengaruh secara signifikan terhadap proses pembelajaran. Selanjutnya kepemimpinan untuk pembelajaran dilaksanakan dengan menerapkan lima prinsip sebagai berikut: 1) Fokus pada pembelajaran: menyediakan proses pembelajaran yang berkualitas, yang mampu mengembangkan keseluruhan potensi peserta didik secara optimal, dan dapat mengembangkan kapasitas kelembagaan sekolah; 2) Kondisi pembelajaran: menyediakan dan mengoptimalkan sumberdaya (personal, material, dan finansial) untuk menjamin proses pembelajaran yang berkualitas; 3) Dialog: sejalan dengan sumberdaya terbaik dari organisasi adalah manusia; maka dalam memperkenalkan perubahan dan pembaharuan (inovasi) untuk meningkatkan kualitas pembelajaran, dilakukan melalui dialog untuk mencapai kesepahaman dan kesepakatan bersama, serta komitmen untuk pelaksanaannya; 4) Berbagai kepemimpinan: para pihak dalam proses pembelajaran harus saling bersinergi untuk memastikan bahwa peserta didik mempelajari sesuatu yang baru dalam setiap hari belajarnya; 5) Berbagi akuntabilitas: di antara sekolah, dinas pendidikan setempat, dan pengawas. Pada saat berbagi kepemimpinan sesungguhnya juga terjadi berbagi akuntabilitas, yang pada akhirnya dapat memperkuat rasa kepemilikan, menciptakan perasaan saling membutuhkan; yang merupakan sumber penting untuk pengembangan profesional.

Uraian dan gambaran di atas menunjukkan bahwa kepemimpinan (untuk) pembelajaran dapat dijadikan strategi pengembangan peserta didik yang berkarakter, bermoral, humanis dan profesional; sehingga yang bersangkutan dapat menjalankan peran yang baik sebagai manusia dalam pergaulan dengan sesama, dalam kehidupan keluarga, dalam lingkungan sosial, sebagai warga masyarakat dan warga negara yang demokratis, sebagai pekerja profesional, dan pada akhirnya peran sebagai insan yang beriman dan bertakwa kepada Tuhan Maha Pencipta.

\section{SIMPULAN}

Upaya mendidik generasi muda untuk menjadi insan yang berkarakter mulia, sebagai insan yang bermoral, humanis, dan profesional tidaklah semudah membalik tangan; namun juga tidak mustahil untuk dilakukan oleh semua pihak yang berkepentingan dalam pendidikan. Kepemimpinan (untuk) pembelajaran, sebagaimana digambarkan di atas tampak menjanjikan untuk dijadikan strategi dan solusi untuk memantapkan pendidikan karakter di tanah air. Sehubungan dengan itu direkomendasikan kepada para pemangku kepentingan pendidikan untuk melakukan sinergi dengan sepenuh hati guna merancang berbagai program dan aktivitas pendidikan atau pembelajaran yang secara jelas dan tegas menuju kepada pembentukan karakter mulia di atas; mendukung pelaksanaan proses pembelajaran sesuai dengan tingkatan dan cakupan kewenangannya, dan berpartisipasi dalam me-mantau dan mengevaluasi kinerja proses pem-belajaran tersebut. Hanya dengan kesungguhan hati dan keterlibatan aktif seluruh pemangku kepentingan pendidikan itulah dapat diharapkan keberhasilan upaya membentuk generasi yang bermoral, humanis dan profesional.

\section{DAFTAR PUSTAKA}

American Media. (2000). Managing from the heart: Training leader's guide. Urbandale: American Media, a PROVANT Company. ami@ammedia.com. 
Brown, G.T.L. \& Chai, C. (2012). Assessing instructional leadership: a longitudinal study of new principals. Journal of Educational Administration. Vol. 50 No. 6, 2012 p.p. 753-772. www.emeraldinsight.com/0957 8234.htm

Bush, T. (2011). Theories of educational leadership and management. (4th ed.). London: SAGE Publications Ltd.

Crawford, M. (2009). Getting to the heart of leadership: Emotion and educational leadership. London: SAGE Publications Ltd.

Duignan, P.A. \& Macpherson, R.J.S. (eds.). (1992). Educative leadership: A practical theory for new administrators and managers. London-Washington D.C.: The Falmer Press.

Fahri, K. (2010). Positive management education: creating creative minds, passionate hearts, kindred spirits. Journal of Management Education, 35(2), pp. 198-226.

Fry, L.W. (2003). Toward a theory of spiritual leadership. The Leadership Quarterly $14 \quad$ (2003) 693-727 www.sciencedirect.com

Gavin T.L. Brown \& Constance Chai. (2012) Assessing instructional leadership: A longitudinal study of new principals. Journal of Educational Administration. Vol. 50 No. 6, 2012 pp. 753-772. Emerald Group Publishing Limited. www.emeraldinsight.com/09578234.htm

Hallinger, P. (2009). Leadership for 21st century schools: From instructional leadership to leadership for learning. Hong Kong: The Hong Kong Institute of Education.

Hallinger, P. (2010). Leadership for learning: lessons from 40 years of empirical research. Journal of Educational Administration. Vol. 49 No. 2, 2011 pp. 125-142. Emerald Group Publishing Limited. www.emeraldinsight.com/09578234.htm

Knapp, M.S. et al. (2006). Leading, learning, and leadership support. Washington: the Center for the Study of Teaching and Policy (CTP) University of Washington.

MacBeath, J. (2012). Leadership for learning: Concepts, principles and practice. Leadership for Learning. The Cambridge Network.

Madjelis Luhur Persatuan Taman Siswa Jogjakarta. (1961). Karja Ki Hadjar Dewantara. Bagian pertama: Pendidikan. Jogjakarta: Pertjetakan Taman Siswa.

Ministry of Education NSW. Leadership for learning: Understanding the Knowledge and Practice of Effective Principals.

The Wallace Foundation. (2007). Education leadership: A Bridge to School Reform. The Wallace Foundation's National Conference. New York City, October 22-24, 2007.

Townsend, T. \& MacBeath, J. (eds.). (2011). International Handbook of Leadership for Learning. London: Springer Science \& Business Media B.V.

Vogel, L.R. (2012). Leading with Hearts and Minds: Ethical Orientations of Educational Ledership Doctoral Students. Values and Ethics in Educational Administration. March 2012, Volume 10 Number 1 p.1-12

Wagner, T. (2008). The global achievement gap: Why even our best schools don't teach the new survival skills our children need - and what we can do about it. New York: Basic books.

Whitaker, B. (1997). Instructional Leadership and Principal Visibility. The Clearing House; January - February 1997; 70, 3 ProQuest, p. 155-156.

Wigglesworth, C. (2011). Spiritual Intelligence and Why It Matters. Deep Change Distinctive Results www.deepchange.com. 